\title{
Mikrolevien käyttö kotieläinten ravitsemuksessa
}

Marjukka Lamminen

Maataloustieteiden laitos, PL 28, 00014 Helsingin yliopisto, marjukka.lamminen@ helsinki.fi

\section{Tiivistelmä}

Mikrolevät ovat fotosynteesiin kykeneviä mikroskooppisen pieniä yksisoluisia eliöitä. Niitä voidaan hyödyntää muun muassa biopolttoaineiden tuotannossa, ihmis- ja eläinravitsemuksessa, lannoitteiden raaka-aineena ja jätevesien puhdistuksessa. Mikrolevät kasvavat nopeasti, niiden vaatimat kasvuolosuhteet ovat vaatimattomat ja tuottavuus maa-alaa kohden on suuri. Nämä ominaisuudet ovat erityisen kiinnostavia maapallon viljelypinta-alan ollessa rajallinen, väestömäärän lisääntyessä ja eläinperäisten tuotteiden kysynnän kasvaessa.

Mikrolevien valkuaispitoisuus on suuri ja ne sisältävät runsaasti ihmis- ja eläinravitsemuksen kannalta tärkeitä aminohappoja sekä omega-rasvahappoja ja muita monityydyttymättömiä rasvahappoja. Mikrolevät sisältävät raakavalkuaista keskimäärin 500-700 g/kg ka, hiilihydraatteja 100-200 g/kg ka ja lipidejä 50-200 g/kg ka, joskin lajien välinen vaihtelu on suurta. Märehtijöiden ravinnoksi mikrolevät soveltuvat koostumuksensa perusteella hyvin. Sen sijaan yksimahaisten ravitsemuksessa mikrolevien käyttöä saattaa rajoittaa niiden suuri nukleiinihappo- ja selluloosapitoisuus.

Mikrolevien käyttöä lisäravinteena ja niiden vaikutusta maidon ja lihan tuotantoon ja näiden koostumukseen on tutkittu jossain määrin. Sen sijaan vähemmän tutkittu aihe on se, voidaanko mikrolevillä korvata ruokinnan valkuaisrehuja. Ruokinnan sisältäessä levää märehtijöiden kuivaaineen syönnin on raportoitu sekä vähenevän että pysyvän ennallaan. Suurimmassa osassa tutkimuksista vaikutuksia ei ole havaittu maitotuotoksessa eikä maidon valkuaispitoisuudessa. Sen sijaan maidon rasvapitoisuuden väheneminen ja maidon rasvahappokoostumuksessa tapahtuneet muutokset ovat tyypillisiä ruokinnan levälisän vaikutuksia. Monityydyttymättömien rasvahappojen määrä lisääntyy ja tyydyttyneiden rasvahappojen vähentyy. Jo melko pieni pitoisuus levää rehuannoksessa $(10 \mathrm{~g} / \mathrm{kg} \quad \mathrm{ka})$ on ollut riittävän suuri aiheuttamaan muutoksia maidon rasvapitoisuudessa ja rasvan koostumuksessa.

Nämä muutokset johtuvat mikrolevien sisältämästä dokosaheksaeenihaposta (DHA), joka aiheuttaa linolihapon ja linoleenihapon epätäydellisen biohydrogenaation pötsissä. Tällöin biohydrogenaation välituotteiden määrä lisääntyy. Osalla näistä välituotteista on osoitettu olevan maitorauhasen lipidiaineenvaihduntaa estävä vaikutus. Muutoksia tapahtuu myös pötsin mikrobistossa. Levälisän on havaittu alentavan myös metaanintuotantoa in vitro -kokeissa, mutta tätä tulosta ei ole onnistuttu toistamaan in vivo -kokeissa.

Yksimahaisten eläinten ravitsemuksessa levälisän ei ole raportoitu vaikuttavan elopainoon eikä rehuhyötysuhteeseen. Sen sijaan lihan ja kananmunien rasvahappokoostumuksessa on havaittu samanlaisia muutoksia kuin maidossakin. Sikojen sperman laadun ja kananmunien hedelmöittymisen on havaittu paranevan. Myös vasikoiden, lihasikojen ja munijakanojen suoliston maitohappobakteerien määrän on raportoitu lisääntyvän.

Asiasanat: mikrolevä, kotieläinravitsemus, monityydyttymättömät rasvahapot, DHA 


\section{Johdanto}

Mikrolevät ovat prokaryootteja tai eukaryootteja mikro-organismeja, jotka kykenevät fotosynteesiin (Wang ym. 2008). Mikroleviä on kymmeniätuhansia eri lajeja, niitä esiintyy hyvin monenlaisissa ekosysteemeissä ja vaihtelevissa ympäristöissä (Mata ym. 2013). Mikrolevät muodostavat ainakin 50 \% maapallon fotosynteesin kautta tapahtuvasta biomassan tuotannosta (Christi 2006). Mikrolevät kasvavat maanpäällisiä kasveja huomattavasti nopeammin ja niiden hiilidioksidin pidättämisteho on noin 10-50 kertaa suurempi (Demirbas 2006, ref. Li ym. 2008). Erilaiset Chlorella-lajikkeet ovat tutkituista mikrolevistä nopeimmin kasvavia. Chlorella sp. 800-lajikkeen kasvunopeudeksi on mitattu 0,495 g/l/pv. (Hempel ym. 2012).

Mikrolevät ovat ympäristöystävällisiä ja tuottoisia biopolttoaineiden ja muiden bio-tuotteiden raaka-aineita (Mata ym. 2013). Paitsi polttoaineena, niitä voidaan käyttää ihmisten ja eläinten ravintona ja ravintolisinä sekä biomateriaalien ja lannoitteiden raaka-aineena (Christi 2006). Mikroleviä voidaan hyödyntää myös jätevesien puhdistuksessa ja kasvihuonekaasupäästöjen kontrolloinnissa (Mata ym. 2013). Tällä hetkellä 30 \% maailman levätuotannosta hyödynnetään eläinten rehuna (Milledge 2011). Mikrolevien valkuaisen koostumus vastaa muita valkuaisrehuja ja ne sisältävät runsaasti ihmisravitsemuksen kannalta tärkeitä omega-rasvahappoja. Leväntuotannon etuna on myös se, että se ei kilpaile maa-alasta ruuantuotannon kanssa, sillä sitä voidaan kasvattaa muuhun maatalouskäyttöön sopimattomilla mailla (Mata ym. 2013). Rasvatuotokseen suhteutettuna mikrolevien tuotannossa myös tarvitaan 49 ja 132 kertaa vähemmän maa-alaa kuin rypsin ja soijan tuotannossa (Christi 2007).

\section{Levän ravitsemukselliset ominaisuudet}

Mikrolevät sisältävät valkuaista $60-710 \mathrm{~g} / \mathrm{kg} \mathrm{ka}$, hiilihydraatteja $40-640 \mathrm{~g} / \mathrm{kg}$ ka ja lipidejä 20-220 $\mathrm{g} / \mathrm{kg} \mathrm{ka}$ ja lajien väliset vaihtelut ovat suuria (taulukko 1). Taulukossa 1 listatuista levistä vain muutamaa lajia hyödynnetään laajamittaisessa leväntuotannossa. Näitä ovat Chlorophyceae-suvun, eli varsinaisten viherlevien, Chlorella sp. ja Scenedesmus obliquus ja syanobakteeri Spirulina sp (käytetään myös nimitystä Arthrospira sp.). (Becker 2007). Rottakokeissa Spirulinan ei ole havaittu olevan pitkäaikaisessakaan käytössä myrkyllinen tai muutoin haitallinen (Sixabela ym 2001). Eläinten rehuina voidaan hyödyntää sekä tuoretta levälietettä, kuivattua jauhetta että levästä erotettua öljyä. Jauhe voi olla myös biopolttoainetuotannon sivutuote, jolloin siitä on uutettu osa lipideistä pois. Erityyppisiä levävalmisteita on vertailtu varsin vähän eläinten ruokintatutkimuksissa. Stamey ym (2012) havaitsivat tutkimuksessaan pötsisuojatun leväbiomassan saavan aikaan suuremman maidon DHA-tuotoksen kuin pötsisuojattu leväöljy.

Taulukko 1. Eri levälajien ravintoainekoostumus (g/kg ka) (Becker 2007).

\begin{tabular}{llll}
\hline Levälaji & Valkuainen & Hiilihydraatit & Lipidit \\
\hline Anabaena cylindrica & $250-300$ & $40-90$ & $40-70$ \\
Aphanizomenon flos-aquae & 620 & 230 & 30 \\
Chlamydomonas rheinhardii & 480 & 170 & 210 \\
Chlorella pyrenoidosa & 570 & 260 & 20 \\
Chlorella vulgaris & $510-580$ & $120-170$ & $140-220$ \\
Dunaliella salina & 570 & 320 & 60 \\
Euglena gracilis & $390-610$ & $140-180$ & $140-200$ \\
Porphyridium cruentum & $280-390$ & $400-570$ & $90-140$ \\
Scenedesmus obliquus & $500-560$ & $100-170$ & $120-140$ \\
Spirogyra sp. & $60-200$ & $330-640$ & $110-210$ \\
Spirulina maxima & $600-710$ & $130-160$ & $60-70$ \\
Spirulina platensis & $460-630$ & $80-140$ & $40-90$ \\
Synechococcus sp. & 630 & 150 & 110 \\
\hline
\end{tabular}

Useimmat kirjallisuudessa esitetyt luvut levien valkuaispitoisuudesta on esitetty raakavalkuaisena. Tämä kuitenkin yliarvioi levien todellista valkuaispitoisuutta, sillä valkuaisen lisäksi levissä on myös muita typpeä sisältäviä ainesosia (nukleiinihapot, amiinit, glukosamidit ja solunseinämäaineet). Eivalkuaistypen osuuden on arvioitu olevan $12 \%$ Scenedesmus obliquus-lajilla, 11,5\% Spirulinalla ja 6 $\%$ Dunaliellalla. (Becker 2007). 
Kirjallisuuden mukaan levien käyttöä ihmisten ja yksimahaisten eläinten ravitsemuksessa saattaa rajoittaa niiden huono sulavuus, joka johtuu solunseinämäaineksen suuresta selluloosapitoisuudesta. Poikkeuksena tästä on Spirulina. (Becker 1994 ref. Milledge 2011). Levien selluloosapitoisen soluseinämän osuus koko kasvuston kuiva-aineesta on noin $10 \%$ (Becker 2007). Wullepitin ym. (2012) ja Boeckaertin ym. (2007a) tutkimuksissa mikrolevän (Schizochytrium sp.) ei kuitenkaan havaittu sisältävän lainkaan neutraalidetergenttikuitua. Mikrolevien käyttö märehtijöiden ruokinnassa on mahdollista sellaisenaan (Becker 1994 ref. Milledge 2011), mutta yksimahaisia eläimiä ruokittaessa levämassa on prosessoitava sulavuuden parantamiseksi (Becker 2007). Sioilla mikrolevien valkuaisen näennäisen sulavuuden on raportoitu olevan 55-77 \% (Henman 2012). Mikrolevien käyttöä eläinten ruokinnassa voi rajoittaa myös niiden nukleiinihappopitoisuus, joka on tavallisesti $40-60 \mathrm{~g} / \mathrm{kg}$ ka. Siipikarjan ruokinnassa mikrolevillä voidaan turvallisesti korvata 5-10 \% tavallisista valkuaisrehuista. Suurempien pitoisuuksien on raportoitu heikentävän kasvua ja rehuhyötysuhdetta. (Becker 2004). Sikojen ruokinnassa mikrolevillä voidaan korvata ainakin 10-20\% tavallisista valkuaisrehuista (Henman 2012).

Tutkittujen mikrolevälajien on havaittu sisältävän 37 erilaista rasvahappoa. Näistä palmitiinihappo (C16:0), palmitoleiinihappo (C16:1), steariinihappo (C18:0), öljyhappo (C18:1 $\omega 9)$,

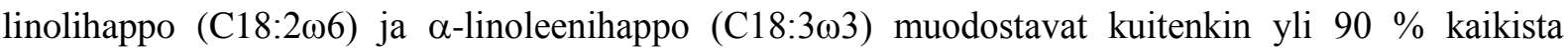
rasvahapoista. (Hempel ym. 2012). Lähes kaikkien levien aminohappokoostumus on muiden valkuaislähteiden veroinen, joskin rikkipitoisten aminohappojen (metioniini, kystiini) pitoisuus on monien muiden kasviproteiinien tavoin pieni (taulukko 2).

Taulukko 2. Eri levälajien aminohappokoostumus kananmunan ja soijan aminohappokoostumukseen verrattuna (g/100g valkuaista) (Becker 2007).

\begin{tabular}{lccccccccccccccccccc}
\hline Ravintoaine & Ile & Leu & Val & Lys & Phe & Tyr & Met & Cys & Try & Thr & Ala & Arg & Asp & Glu & Gly & His & Pro & Ser \\
\hline Kananmuna & 6,6 & 8,8 & 7,2 & 5,3 & 5,8 & 4,2 & 3,2 & 2,3 & 1,7 & 5 & - & 6,2 & 11 & 13 & 4,2 & 2,4 & 4,2 & 6,9 \\
Soija & 5,3 & 7,7 & 5,3 & 6,4 & 5 & 3,7 & 1,3 & 1,9 & 1,4 & 4 & 5 & 7,4 & 1,3 & 19 & 4,5 & 2,6 & 5,3 & 5,8 \\
Chlorella vulgaris & 3,8 & 8,8 & 5,5 & 8,4 & 5 & 3,4 & 2,2 & 1,4 & 2,1 & 4,8 & 7,9 & 6,4 & 9 & 12 & 5,8 & 2 & 4,8 & 4,1 \\
Dunaliella bardawil & 4,2 & 11 & 5,8 & 7 & 5,8 & 3,7 & 2,3 & 1,2 & 0,7 & 5,4 & 7,3 & 7,3 & 10,4 & 13 & 5,5 & 1,8 & 3,3 & 4,6 \\
Scenedesmus obliquus & 3,6 & 7,3 & 6 & 5,6 & 4,8 & 3,2 & 1,5 & 0,6 & 0,3 & 5,1 & 9 & 7,1 & 8,4 & 11 & 7,1 & 2,1 & 3,9 & 3,8 \\
Spirulina maxima & 6,0 & 8 & 6,5 & 4,6 & 4,9 & 3,9 & 1,4 & 0,4 & 1,4 & 4,6 & 6,8 & 6,5 & 8,6 & 13 & 4,8 & 1,8 & 3,9 & 4,2 \\
Spirulina platensis & 6,7 & 9,8 & 7,1 & 4,8 & 5,3 & 5,3 & 2,5 & 0,9 & 0,3 & 6,2 & 9,5 & 7,3 & 11,8 & 10 & 5,7 & 2,2 & 4,2 & 5,1 \\
Aphanizomenon sp. & 2,9 & 5,2 & 3,2 & 3,5 & 2,5 & - & 0,7 & 0,2 & 0,7 & 3,3 & 4,7 & 3,8 & 4,7 & 7,8 & 2,9 & 0,9 & 2,9 & 2,9 \\
\hline
\end{tabular}

\section{Leväruokinnan vaikutukset maidontuotantoon}

Levälisän ei ole raportoitu vaikuttavan nautojen ja lampaiden kuiva-aineen syöntiin (Stamey ym. 2012, Wullepit ym. 2012, Bichi ym. 2013) tai syönti on vähentynyt (Franklin ym. 1999, Papadopoulos ym. 2002, Boeckaert ym. 2008a, Toral ym. 2010, Moate ym. 2013). Ruokinnan levälisän ei suurimmassa osassa tutkimuksista ole havaittu vaikuttavan lehmien (Papadopoulos ym. 2002, AbuGhazaleh ym. 2009, Christaki ym. 2012, Glover ym. 2012, Karatzia ym. 2012, Stamey ym. 2012, Wullepit ym. 2012, Moate ym. 2013) eikä lampaiden (Bichi ym. 2013) maitotuotokseen. Yksittäisissä tutkimuksissa levälisä on kuitenkin vähentänyt (Boeckaert ym. 2008a) tai lisännyt (Hostens ym. 2011) maitotuotosta. Suurimmassa osassa tutkimuksista ei myöskään ole havaittu vaikutusta maidon valkuaispitoisuuteen (Boeckaert ym. 2008a, AbuGhazaleh ym. 2009, Hostens ym. 2011, Karatzia ym. 2012, Stamey ym. 2012, Wullepit ym. 2012, Moate ym. 2013). Papadopoulosin ym. (2002) tutkimuksessa lehmänmaidon valkuaispitoisuus kohosi leväruokinnalla.

Levälisän on todettu alentavan lypsylehmien (Franklin ym. 1999, Boeckaert ym. 2008a, Hostens ym. 2011, Glover ym. 2012, Moate ym. 2013, Wullepit ym. 2012) ja lypsyrotuisten lampaiden (Bichi ym. 2013) maidon rasvapitoisuutta. Toisaalta on myös raportoitu, ettei leväruokinnalla olisi vaikutusta lehmänmaidon rasvapitoisuuteen (AbuGhazaleh ym. 2009, Karatzia ym. 2012, Stamey ym. 2012) ja että leväruokinta lisää uuhenmaidon rasvapitoisuutta (Papadopoulos ym. 2002). Toral ym. (2010) ja Bichi ym. (2013) havaitsivat leväruokinnan alentavan maidon rasvapitoisuutta vasta 13-18 päivän kuluttua leväruokinnan aloituksesta. 
Boeckaert ym. (2008a) havaitsivat leväruokinnan lisäävän maidon CLA cis-9 trans-11, CLA trans-9 cis-11, C18:2 trans-11 cis-15, C18:1 trans -rasvahappojen ja DHA:n pitoisuuksia. Sen sijaan tyydyttymättömien rasvahappojen, erityisesti C18:0 rasvahapon, pitoisuudet maidossa alenivat. Jo 10 $\mathrm{g} / \mathrm{kg}$ ka ruokinnan leväpitoisuus oli riittävä alentamaan maidon rasvapitoisuutta ja muokkaamaan maidon rasvahappokoostumusta. (Boeckaert ym. 2008a).

Levän sisältämän dokosaheksaeenihapon (DHA, C22:6 n-3) on osoitettu aiheuttavan linolihapon (C18:2 n-6) ja linoleenihapon (C18:3 n-3) rasvahappojen epätäydellisen biohydrogenaation. Tälloin biohydrogenaation välituotteiden C18:2 trans-11 cis-15, CLA cis-9 trans11 ja C18:1 trans-isomeerien pitoisuudet ovat kohonneet pötsissä. (Boeckaert ym. 2007b). Pötsin lyhytketjuisten rasvahappojen tuotannon on in vitro -kokeissa havaittu alentuvan, kun EPA+DHApitoisuus ylittää $0,169 \mathrm{mg} / \mathrm{ml}$ inkubaatioliuosta (Fievez ym. 2007).

Leväruokinnan vaikutusta pötsin mikrobistoon on tutkittu varsin vähän. Muutoksia on havaittu sekä bakteeri- että alkueläinpopulaatioiden koostumuksessa ja alkueläinten määrässä (Boeckaert ym. 2007a). Toisessa tutkimuksessa ei havaittu muutoksia bakteerien eikä alkueläinten määrässä. Sen sijaan Butyrivibrio-ryhmän bakteerien lajiston koostumuksessa, erityisesti Butyrivibrio- ja Pseudobutyrivibrio-sukujen välimaastoon asettuvissa viljelemättömissä lajeissa, oli tapahtunut muutoksia. (Boeckaert ym. 2008b). Useissa tutkimuksissa on raportoitu Butyrivibrio-ryhmän bakteereilla olevan aktiivinen rooli tyydyttymättömien C18-rasvahappojen biohydrogenaatiossa (Jenkins ym. 2008).

Biohydrogenaation välituotteista CLA trans-10 cis-12, CLA cis-10 trans-12 ja CLA trans-9 cis11:1la on osoitettu olevan maitorauhasen lipidiaineenvaihduntaa estävä vaikutus (Shingfield ja Griinari 2007). Boeckaertin ym. (2008a) mukaan nämä eivät kuitenkaan aiheuta leväruokinnalla maitorasvan depressiota. Sen sijaan saatavilla olevan C18:0 rasvahapon määrän maitorauhaskudoksen C18:1 c9 rasvahapposynteesiä varten on raportoitu rajoittavan maitorasvan tuotantoa (Boeckaert ym. 2008a).

Levälisän sisältämän DHA:n on in vitro -kokeissa havaittu vähentävän pötsin metaanintuotantoa enimmillään jopa 80-98 \% (Fievez ym. 2007, Bozic ym. 2009). Fievezin ym (2007) tutkimuksessa metaanintuotannon vähentyessä myös asetaatin ja butyraatin osuus vähentyi ja propionaatin lisääntyi. Korkeat DHA-tasot (EPA+DHA yli $0,169 \mathrm{mg} / \mathrm{ml}$ inkubaatioliuosta) vaikuttavat olevan yksinään suoraan myrkyllisiä pötsin metanogeeneille. Sen sijaan matalammilla tasoilla vaikutus on epäsuora ja metaanintuotannon väheneminen johtuu substraatin (vety) puutteesta. Tämän perusteella pötsin metanogeeneille vetyä toimittava bakteeri on herkempi DHA:lle kuin itse metanogeenit. (Fievez ym. 2007). In vivo -kokeessa levän DHA:n (suurin annos 75g DHA/pv) ei sen sijaan havaittu vaikuttavan metaanin kokonaispäästöihin tai päästöihin maitokiloa kohden (Moate ym. 2013).

\section{Leväruokinnan vaikutus kasvuun sekä lihan- ja kananmunientuotantoon}

Levälisällä ei ole ollut vaikutusta vasikoiden (Heidarpour ym. 2011), lihasikojen (Yan ym. 2012) eikä kanien (Peiretti ja Meineri 2008) elopainoon eikä rehuhyötysuhteeseen. Pienen levälisän $(1 \mathrm{~g} / \mathrm{kg} \mathrm{ka}$ rehua) on raportoitu parantavan sikojen päiväkasvua (Yan ym. 2012), mutta vasikoilla ja kaneilla tällaista vaikutusta ei ole havaittu (Heidarpour ym. 2011, Peiretti ja Meineri 2008). Grinstead ym. (2000) saivat vieroitetuilla porsailla tehdyssä tutkimuksessaan vaihtelevia ja vain vähäisiä parannuksia levälisää saaneiden eläinten kasvutuloksissa.

Ruokinnan levälisän on raportoitu lisänneen lihan DHA-pitoisuutta sioilla, sen sijaan muutoksia ei havaittu lihan rasvahappokoostumuksessa (Sardi ym. 2006). Kaneilla levälisän on havaittu vähentäneen lihan tyydyttyneiden ja kertatyydyttymättömien ja lisänneen monityydyttymättömien rasvahappojen pitoisuuksia (Peiretti ja Meineri 2011). Kananmunien tuotannossa levälisän on havaittu parantavan munantuotantoa, keltuaisen väriä (Jeon ym. 2012, Mariey ym. 2012), lisäävän munien luteiinipitoisuutta ja kohottavan Haughin yksikköä (Jeon ym. 2012). Mariey ym. (2012) raportoivat leväruokinnan lisäävän myös kananmunien massaa ja keltuaisen osuutta, parantavan rehuhyötysuhdetta ja alentavan sekä keltuaisen että plasman kolesterolipitoisuutta. Vaikutuksia ei havaittu munankuoren laadussa eikä sen osuudessa koko kananmunasta (Jeon ym. 2012, Mariey ym. 2012).

\section{Terveys ja hedelmällisyys}

Levälisän on raportoitu parantaneen karjujen sperman laatua ja määrää, pidentävän siittiöiden elinikää (Kistanova ym. 2009) ja liikkuvuutta sekä nostaneen emakoiden porsimisprosenttia ja syntyneiden 
porsaiden määrää (Vera 2007). Leväruokinnan on myös raportoitu parantaneen erittäin merkitsevästi kananmunien hedelmöittyvyyttä ja kuoriutumisprosenttia (Mariey ym. 2012).

Levälisä saattaa parantaa eläinten suolistoterveyttä. Levälisä on lisännyt ulosteen Lactobacillusbakteerien määrää lihasioilla (Yan ym. 2012) ja vasikoilla (Kuzmaite ym. 2009) ja umpisuolen maitohappobakteerien määrää munijakanoilla (Zheng ym. 2012). Levälisän havaittiin alentavan sikojen ulosteen E. coli-bakteerien määrää (Yan ym. 2012) ja vasikoilla Enterococcus-bakteerien määrää, vaikkakaan tulos ei ollut tilastollisesti merkitsevä (Kuzmaite ym 2009).

\section{Johtopäätökset}

Tämän kirjallisuusselvityksen perusteella mikrolevillä on monia mahdollisia sovelluksia kotieläinten ruokinnassa. Niitä voitaisiin mahdollisesti hyödyntää paitsi valkuaisrehuna, myös rehulisäaineina, joilla voidaan muokata eläintuotteiden rasvapitoisuutta ja rasvahappokoostumusta ihmisravitsemukselle suotuisammaksi. Levien syötöllä voi olla myös terveydellisiä etuja. Levien käyttöä kotieläinten ruokinnassa saattaa rajoittaa niiden nukleiinihappo- ja selluloosapitoisuus sekä alhainen rikkipitoisten aminohappojen pitoisuus.

\section{Kirjallisuus}

AbuGhazaleh, A.A., Potu, R.B. \& Ibrahim, S. 2009. The effect of substituting fish oil in dairy cow diets with docosahexaenoic acid-micro algae on milk composition and fatty acids profile. Journal of Dairy Science 92:6156-6159.

Becker, E.W.1994. Microalgae. Biotechnology and Microbiology. Cambridge, UK: Cambridge University Press. $230 \mathrm{~s}$.

Becker, W. 2004. Microalgae in human and animal nutrition. Teoksessa: Richmond, A. (toim.), Handbook of Microalgal Culture. Blackwell, Oxford. s. 312-351.

Becker, E.W. 2007. Micro-algae as a source of protein. Biotechnology Advances 25:207-210

Bichi, E. , Hervás, G., Toral, P.G., Loor, J.J. \& Frutos, P. 2013. Milk fat depression induced by dietary marine algae in dairy ewes: Persistency of milk fatty acid composition and animal performance responses. Journal of Dairy Science 96:524-532.

Boeckaert, C., Vlaeminck, B., Dijkstra, J., Issa-Zacharia, A., Van Nespen, T., Van Straalen, W. \& Fievez, V. 2008a. Effect of dietary starch or micro algae supplementation on rumen fermentation and milk fatty acid composition of dairy cows. Journal of Dairy Science 91:4714-4727.

Boeckaert, C., Vlaeminck, B., Fievez, V., Maignien, L., Dijkstra, J. \& Boon, N. 2008b. Accumulation of trans C18:1 fatty acids in the rumen after dietary algal supplementation is associated with changes in the Butyrivibrio community. Applied and Environmental Microbiology 74(22):69236930.

Boeckaert, C., Fievez, V., Van Hecke, D., Verstraete, W. \& Boon, N. 2007a. Changes in rumen biohydrogenation intermediates and ciliate protozoa diversity after algae supplementation to dairy cattle. European Journal of Lipid Science and Technology 109:767-777.

Boeckaert, C., Vlaeminck, B., Mestdagh, J. \& Fievez, V. 2007b. In vitro examination of DHAedible micro algae 1. Effect on rumen lipolysis and biohydrogenation of linoleic and linolenic acids. Animal Feed Science and Technology 136:63-79.

Bozic, A.K., Anderson, R.C., Carstens, G.E., Ricke, S.C., Callaway, T.R., Yokoyama, M.T., Wang, J.K. \& Nisbet, D.J. 2009. Effects of the methane-inhibitors nitrate, nitroethane, lauric acid, Lauricidin and the Hawaiian marine algae Chaetoceros on ruminal fermentation in vitro. Bioresource Technology 100:4017-4025.

Christaki, E., Karatzia, M., Bonos, E., Florou-Paneri, P. \& Karatzias, C. 2012. Effect of dietary Spirulina platensis on milk fatty acid profile of dairy cows. Asian Journal of Animal and Veterinary Advances 7(7):597-604.

Chisti, Y. 2006 Microalgae as sustainable cell factories. Environmental Engineering and Management Journal 5(3):261-274.

Chisti, Y. 2007. Biodiesel from microalgae. Biotechnology Advances 25:294-306

Demirbas, A. 2006. Oily products from mosses and algae via pyrolysis. Energy Sources, part A: Recovery, Utilization, and Environmental Effects 28:933-940. 
Fievez, V., Boeckaert, C., Vlaeminck, B., Mestdagh, J. \& Demeyer, D. 2007. In vitro examination of DHA-edible micro-algae 2. Effect on rumen methane production and apparent degradability of hay. Animal Feed Science and Technology 136:80-95.

Franklin S.T., Martin, K.R., Baer, R.J., Schingoethe, D.J. \& Hippen, A.R. 1999. Dietary marine algae (Schizochytrium sp.) increases concentrations of conjugated linoleic, docosahexaenoic and transvaccenic acids in milk of dairy cows. The Journal of Nutrition 129(11): 2048-2054.

Glover, K.E., Budge, S., Rose, M., Rupasinghe, H.P.V., MacLaren, L., Green-Johnson, J. \& Fredeen, A.H. 2012. Effect of feeding fresh forage and marine algae on the fatty acid composition and oxidation of milk and butter. Journal of Dairy Science 95:2797-2809.

Gouveia, L. 2011. $\mathrm{CO}_{2}$ Sequestration. Teoksessa: Gouveia, L. (toim.) Microalgae as a Feedstock for Biofuels. Springer. s. 30-33.

Grinstead, G.S., Tokach, M.D., Dritz, S.S., Goodband, R.D. \& Nelssen, J.L. 2000. Effects of Spirulina platensis on growth performance of weanling pigs. Animal Feed Science 83:237-247.

Heidarpour, A., Fourouzandeh-Shahraki, A.-D. \& Eghbalsaied, S. 2011. Effects of Spirulina platensis on performance, digestibility and serum biochemical parameters of holstein calves. African Journal of Agricultural Research 6(22):5061-5065.

Hempel, N., Petrick, I. \& Behrendt, F. 2012. Biomass productivity and productivity of fatty acids and amino acids of microalgae strains as key characteristics of suitability for biodiesel production. Journal of Applied Phycolocy 24:1407-1418.

Henman, D.J. 2012. Evaluation of algal meal as an energy and protein source in pig diets. Project 4A102. Report prepared for the co-operative research centre for high integrity Australian pork. 12s.

Hostens, M., Fievez, V., Vlaeminck, B., Buyse, J., Leroy, J., Piepers, S., De Vliegher, S. \& Opsomer, G. 2011. The effect of marine algae in the ration of high-yielding dairy cows during transition on metabolic parameters in serum and follicular fluid around parturition. Journal of Dairy Science 94:4603-4615.

Jenkins, T.C., Wallace, R.J., Moate, P.J. \& Mosley, E.E. 2008. Recent advances in biohydrogenation of unsaturated fatty acids within the rumen microbial ecosystem. Journal of Animal Science 86:397-412.

Jeon, J.-Y., Kim, K.-E., Im, H.-J., Oh, S.-T., Lim, S.-U., Kwon, H.-S., Moon, B.-H., Kim, J.-M., An, B.-K. \& Kang, C.-W. 2012. The production of lutein-enriched eggs with dietary Chlorella. Korean Journal for Food Science of Animal Resources 32(1):13-17.

Karatzia, M., Christaki, E., Bonos, E., Karatzias, C. \& Florou-Paneri, P. 2012. The influence of dietary Ascophyllum nodosum on haematologic parameters of dairy cows. Italian Journal of Animal Science 11(e31): 169-173.

Kistanova, E., Marchev, Y., Nedeva, R., Kacheva, D., Shumkov, K., Georgiev, B. \& Shimkus, A. 2009. Effect of the Spirulina platensis included in the main diet on the boar sperm quality. Biotechnology in Animal Husbandry 25(5-6):547-557.

Kuzmaite, I., Oberauskas, V., Kantautaite, J., Sederevicius, A. \& Bakutis, B. 2009. The effect of Chlorella vulgaris IFR-111 on the microflora of the digestive system of neonate calves kept in cold farms. Sustainable animal husbandry: prevention is better than cure, Volume 1. Proceedings of the 14th International Congress of the International Society for Animal Hygiene (ISAH), Vechta, Germany, 19th to 23rd July 2009. s. 235-238.

Li, Y., Horsman, M., Wu, N., Lan, C.Q. \& Dubois-Calero, N. 2008. Biofuels from microalgae. Biotechnology Progress 24:815-820.

Mariey, Y.A., Samak, H.R. \& Ibrahem, M.A. 2012. Effect of using Spirulina platensis algae as a feed additive for poultry diets: 1- Productive and reproductive performances of local laying hens. Egyptian Poultry Science 32(1):201-2015.

Mata, T.M., Martins, A.A., Sikdar, S.K., Costa, C.A.V. \& Caetano, N.S. 2013. Sustainability considerations about microalgae for biodiesel production. Teoksessa: J.W. Lee (toim.) Advanced Biofuels and Bioproducts. Springer Science+Business Media. New York. s. 745-757.

Milledge, J.J. 2011. Commercial application of microalgae other than as biofuels: a brief review. Reviews in Environmental Science and Biotechnology 10:31-41.

Moate, P.J., Williams, S.R.O., Hannah, M.C., Eckard, R.J., Auldist, M.J., Ribaux, B.E., Jacobs, J.L. \& Wales, W.J. 2013. Effects of feeding algal meal high in docosahexaenoic acid on feed intake, milk production, and methane emissions in dairy cows. Journal of Dairy Science 96:3177-3188. 
Papadopoulos, P., Goulas, C., Apostolaki, E. \& Abril, R. 2002. Effects of dietary supplements of algae, containing polyunsaturated fatty acids, on milk yield and the composition of milk products in dairy ewes. Journal of Dairy Research 69:357-365.

Peiretti, P.G. \& Meineri, G. 2008. Effects of diets with increasing levels of Spirulina platensis on the performance and apparent digestibility in growing rabbits. Livestock Science 118: 173-177.

Sardi, L., Martelli, G., Lambertini, L., Parisini, P. \& Mordenti, A. 2006. Effects of a dietary supplement of DHA-rich marine algae on Italian heavy pig production parameters. Livestock Science 103:95-103.

Shingfield, K.J. \& Griinari, J.M. 2007. Role of biohydrogenation intermediates in milk fat depression. European Journal of Lipid Science and Technology 109: 799-816.

Sixabela, P.S.S., Chivandi, E., Badenhorst, M. \& Erlwanger, K.H. 2001. The effects of dietary supplementation with Spirulina platensis in growing rats. Asian Journal of Animal and Veterinary Advances 6(6):609-617.

Spolaore P., Joannis-Cassan C., Duran E. \& Isambet A. 2006 Commercial applications of microalgae. Journal of Bioscience and Bioengineering 101(2):87-96.

Stamey, J.A., Shepherd, D.M., de Veth, M.J. \& Corl, B.A. 2012. Use of algae or algal oil rich in n3 fatty acids as a feed supplement for dairy cattle. Journal of Dairy Science 95:5269-5275.

Toral, P.G., Hervás. G., Gómez-Cortés, P., Frutos, P., Juárez, M. \& de la Fuente, M.A. 2010. Milk fatty acid profile and dairy sheep performance in response to diet supplementation with sunflower oil plus incremental levels of marine algae. Journal of Dairy Science 93:1655-1667.

Vera, G. 2007. Achievements in the artificial insemination of swine. Bulletin of University of Agricultural Sciences and Veterinary Medicine Cluj-Napoca. Animal Science and Biotechnologies 64(1-2):382-386.

Wullepit, N., Hostens, M., Ginneberge, C., Fievez,, V., Opsomer, G., Fremaut, D. \& De Smet, S. 2012. Influence of a marine algae supplementation on the oxidative status of plasma in dairy cows during the periparturient period. Preventive Veterinary Medicine 103:298-303.

Wang, B., Li, Y., Wu, N. \& Lan, C.Q. 2008. $\mathrm{CO}_{2}$ bio-mitigation using microalgae. Applied Microbiology and Biotechnology 79:707-718.

Yan, L., Lim, S.U. \& Kim, I.H. 2012. Effect of fermented Chlorella supplementation on growth performance, nutrient digestibility, blood characteristics, fecal microbial and fecal noxious gas content in growing pigs. Asian-Australian Journal of Animal Science 25(12) : 1742-1747.

Zheng, L., Oh, S.T., Jeon, J.Y., Moon, B.H., Kwon, H.S., Lim, S.U., An, B.K. \& Kang, C.W. 2012. The dietary effects of fermented Chlorella vulgaris (CBT®) on production performance, liver lipids and intestinal microflora in laying hens. Asian-Australian Journal of Animal Science 25(2):262266. 